\title{
Bilateral congenital entropion of the upper eyelids
}

\author{
T. FIRAT AND S. ÖZKAN \\ Department of Ophthalmology, Hacettepe University, Ankara, Turkey
}

Congenital entropion is very rare especially in the upper lid (Mann, I957). A review of the literature has enabled us to assemble fifteen cases (see Bibliography).

\section{Case report}

A 6-month-old baby boy was seen at the Department of Ophthalmology, Hacettepe University Hospital, on July 17,1972 , when the parents stated that the anomaly of the upper lids had been present at birth.

\section{Examination}

There was entropion of two-thirds of both upper lids; the cilia were in contact with the cornea and had caused an oedematous white opacity, presenting small punctate staining areas (Fig. I). The cyes appeared to be otherwise normal, but the fundi could not be seen because of the cloudy corneae.

\section{General examination}

Nothing abnormal was revealed by laboratory tests and radiological examination of the skull and wrists, except that a very slight perihilar infiltration was seen in the lungs.

\section{Treatment}

Both eyelids were corrected by a modified Panas operation under general anaesthesia.

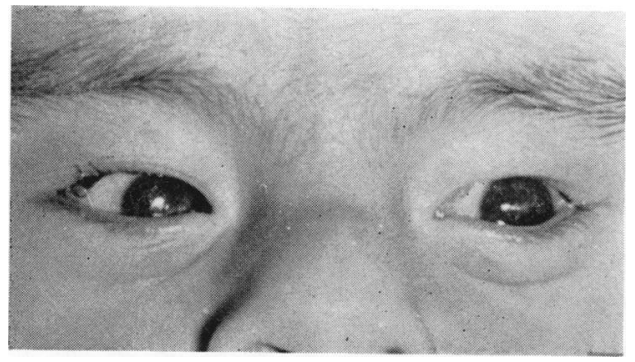

FIG. I. Before operation

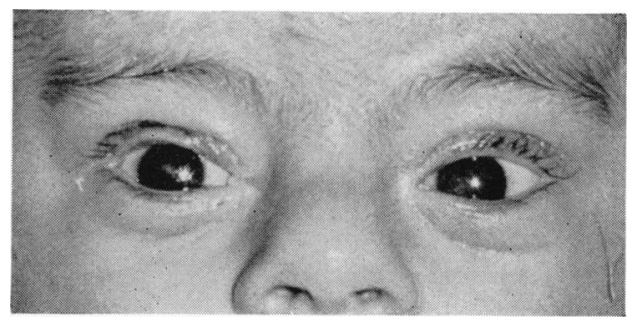

FIG. 2. After operation

\section{Result}

The baby looked very well after the operation and the opacification of the corneae began to clear (Fig. 2). 


\section{Comment}

The cause of this very rare abnormality has been attributed to a lack of the tarsal plate $\frac{\widehat{\varrho}}{3}$ or to reduplication of the Meibomian glands (Duke-Elder, I959). In our case both tarsi were present and of normal thickness. We were unable to verify the other hypothesis $\vec{\Rightarrow}$ because the necessary anatomicopathological investigation was not possible.

\section{Summary}

A rare case of bilateral congenital upper lid entropion is presented. The deformity was successfully corrected by surgery.

\section{Bibliography}

Ammon, F. von (1841) “Klinische Darstellung der Krankheiten des Auges und der Augenlider". 응

Reimer, Berlin.

ARKIN, W. (1935) Klin. oczna, 13, 33 I

aubineau, e. (1928) Ann. Oculist. (Paris), 165, I6 I

chow, к. (1934) Chin. med. f., 48, 830

chow, y. (1925) Klin. Mbl. Augenheilk., 75, 162

Devoe, G. A., and horwich, H. (1954) Arch. Ophthal. (Chicago), 52, 865

DUKe-elder, s. (1964) "System of Ophthalmology", vol. 3, Pt. 2, "Congenital Deformities, p. 863.

Kimpton, London

harlan, G. C. (1896) Trans. Amer. ophthal. Soc., i895, 7, 418

LIPPINCOTT, J. A. (I894) Ibid., I894, 7, 225

MANN, I. (1957) "Developmental Abnormalities of the Eye", 2nd ed., p. 383 . B.M.A., London

PICö, G. (1957) Trans. Amer. ophthal. Soc., 55, 663

REDSlob, E. (1947) Ann. Oculist. (Paris), r8o, 263

schweinitz, G. E. De (I896) Trans. Amer. ophthal. Soc. i 895, 7, 422

Wilde, w. (1844) Dublin F. med. Sci., 27, I

- - ( I 845) Ibid., 28, 8 I 